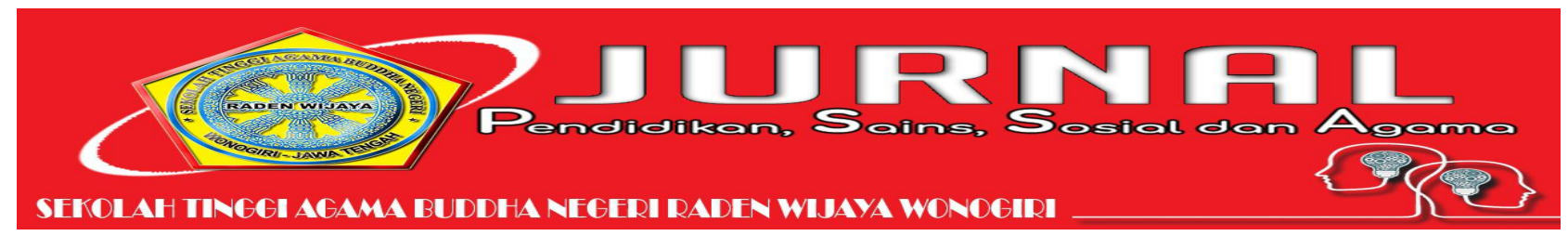

\title{
A STUDY OF AN ERROR ANALYSIS IN SIMPLE PAST TENSE IN TEACHING WRITING
}

\author{
Maulana Yusuf Aditya \\ STKIP PGRI Bangkalan \\ E-mail: aditya@,stkippgri-bkl.ac.id
}

\begin{abstract}
The pupose of this study is To know the error when the student make in simple past tense in teaching writing Recount Text At Eight Grade In SMP Al-Baisuny. The research design that was used in this study is qualitative research. The object of this study was the eight grade students of SMP AL-Baisuny which consists of 25 students In this research, the instruments used was: Student's Worksheet. The result of the analysis shows that: (1) the errors in recount writing made by the eight grade students of SMP AlBaisuny are 82 occurrences of all errors. In term of each type errors, the errors of Overgeneralization 25 times, errors of Ignorance of Rules Restriction 22 times, errors of Incomplete Application of Rules 21 times, and errors of False Concept Hypothesis 14 times.
\end{abstract}

Key Words : Errors, Simple Past Tense, Recount Text Writing

\begin{abstract}
ABSTRAK
Kegunaannya dari penelitian ini adalah Untuk mengetahui kesalahan ketika siswa membuat dalam simple past tense dalam pengajaran menulis recount text pada kelas delapan di SMP Al-Baisuny. Desain penelitian yang digunakan dalam penelitian ini adalah penelitian kualitatif. Tujuan dari penelitian ini adalah siswa kelas delapan SMP AL-Baisuny yang terdiri dari 25 siswa Dalam penelitian ini, instrumen yang digunakan adalah: Lembar Kerja Siswa. Hasil analisis menunjukkan bahwa: (1) kesalahan dalam penghitungan ulang tertulis yang dibuat oleh siswa kelas delapan SMP Al-Baisuny adalah 82 kejadian dari semua kesalahan. Dalam jangka waktu setiap jenis kesalahan, kesalahan dari Overgeneralization 25 kali, kesalahan Ignorance of Rules Restriction 22 kali, kesalahan Incomplete Application of Rules 21 kali, dan kesalahan dari False Concept Hypothesis 14 kali.
\end{abstract}

Kata Kunci: eror, recount text, menulis, simple past tense.

\section{INTRODUCTION}

An error anaysis has an important role to reveal what kinds of error the student do most, to know the causes of the error and how the student can learn from their mistakes in writing by themselves. Thus, the students will not do the same error or make some errors repeatedly.

In fact, students still feel difficult in writing english grammatically. Even though they have studied English for many years and have mastered grammar, they still make many errors when they write. It means grammatical knowledge is needed for writing. Like simple past tense. According Kent Uchiyama (2006: 45 ) said that simple past tense usually means that this action is in the past

Writing Ability always have main concern when the student created written text. Writing ability had been good result if the grammar was perfect. Writing was product skill like made short story, poem, or another written. 
According to Trudy Wallace, Winifred E. Stariba (2000:15) "Writing is the final product of several separate acts that are hugely challenging to learn simultaneously. Among these separable acts are note-taking, identifying a central idea, outlining, drafting and editing". Sometimes, writing is used for test student in their subject at their school. Writing student's recount is a way to make student want to write and write.

Writing itself can be mastered only through learning activities and exercises, because it is unnatural skill and needs serious attempt to aquire it. To be able to write people must learn from kinds of alphabets until how to arrange words become sentences and sentences become a good paragraph based om what they have been stated before, in fact, altough some students have learned grammar completely such as the example above in using tenses, they still find the difficulty to distinguish the usage in every type of tenses. As a result, it will leasd them to produce many errors. Many students commonly make mistakes in their learning. But, many teachers did not aware about this problem and prevent students for making same errors by analyzing the learners' error itself.

Recount text is a kind of text that tell about experience. (Arifian Rosyadi, 2001:1) said that recount text is a piece of text that retells past events, usually in the order in which they happened. In this research, student increased their writing by wrote recount text. They wrote their experience and wrote down into paper in order to be good recount text. Recount text have strong relationship with daily student. So, it made easier for the researcher to got the value of writing recount text of student at SMP Al-Baysuny. In this study, student studied about past tense that tenses in recount text.

Those are the reason why the writer is interested in analyzing students' writing. In this case, the writer wants to find out the grammatical error that's made by the eight grade of junior high school. Because, learning english in junior high school is not just for the introduction anymore. And by knowing the students' errors which are obtained from the test of their recount text writing focuses in their grammar.

The writer hoped this research had been useful for the students in understanding about using simple past tense especially in recount text. Based on the reason above, the writer is interested in analyzing the error in writing focused on simple past tense of recount text.

\section{RESEARCH METHOD}

This research was a qualitative research which needs to be collected by the data from many resources. There were many kinds of design that can be used in the research, it is depended on the research carried out.

The location of the study was in SMP Al-baisuny at the eight grade. The school was chosen as the setting of the study because there was Attractive class. So, the students in that program must have better skill in English (especially in writing skill) and also have a good understanding in writing recount text

The Data Collection Method used Document Review. In the case, Document review in the form of Test to students.the writer gives a test to the eight grade students of SMP Al- 
Baisuny, Kokop. The writer asked the students to write recount text using simple past tense in a piece of paper. The students are asked to make recount text and the topic has been held by the writer, then, the student's assignment is collected. From this, the writer knows the common error made by students in recount text focused on simple past tense

The data are qualitatively analyzed using grammar of english. Besides, they are also analyzed using precentage formula as follows :

$$
P=\frac{F}{N} \times 100 \%
$$

Notes :

$\mathrm{P}:$ precentage

$\mathrm{F}$ : frequency

$\mathrm{N}$ : total of student

\section{RESEARCH FINDING}

1.Kind of error do students make in simple past tense in teaching writing Recount Text

In the first meeting, teacher gave test to students for made simple past tense sentences. In the second meeting, teacher gave test to student for made recount text under the topic of write the student's experience, length of parapraph is at least minimum one paragraph

\section{Overgeneralization}

In the first meeting, student had been made simple past tense.there was student answer . the wrong answer was "he wake up at 05.00 ". it should be "he woke up at 05.00 ". in the second meeting, student made recount text. There were example student worksheet that have error in overgeneralization

\section{$\underline{\text { Student } 1}$}

Last Holiday, me and my family went to the Pelabuhan Ratu Beach. We stay in a small house during 2 days. There were a lots of boat and a lot of fisherman that catch a fish.

First, we enjoyed the beautiful view. And then we sleeps because we are tired. After we sleep, we swimming in the beach until maghrib. Next, we took a shower and prayed maghrib together. Then, we had a dinner and watched TV together. Finally, everybody feel asleep there

We wake up in the morning and after we take a pray subuh together we had a breakfast. In the afternoon we went home. We all very happy

\section{$\underline{\text { Student } 2}$}

I had my adolescence when I were thirteen. It start with acne that showed up on my face. It is very annoying. It lowered my self-esteem and I am embarrassed to come out of my house and play with friends. Fortunately, my Mum gave me a good medicine. In three weeks, the acnes started to vanish although those showed some black spots in my face. That my bad experience with adolescence

The italic and underline words are errors in overgeneralization. Stay should be stayed, sleep should be slept and start should be started. From this answer, student do not understand to put the verb in the sentence of simple past tense

\section{Ignorance of Rules Restriction}

In the first meeting, student had been made simple past tense.there was "Emily is junior high school". the wrong answer was "Emily is junior high school". I t should be "Emily was junior high shool". in the second meeting, student made recount text. There were example student 
worksheet that have error in ignorance of rules restriction.

$\underline{\text { Student } 1}$

Last Holiday, me and my family went to the Pelabuhan Ratu Beach. We stay in a small house during 2 days. There were a lots of boat and a lot of fisherman that catch a fish.

First, we enjoyed the beautiful view. And then we sleeps because we are tired. After we sleep, we swimming in the beach until maghrib. Next, we took a shower and prayed maghrib together. Then, we had a dinner and watched TV together. Finally, everybody feel asleep there

We wake up in the morning and after we take a pray subuh together we had a breakfast. In the afternoon we went home. We all very happy

\section{$\underline{\text { Student } 2}$}

I had my adolescence when I were thirteen. It start with acne that showed up on my face. It is very annoying. It lowered my self-esteem and I am embarrassed to come out of my house and play with friends. Fortunately, my Mum gave me a good medicine. In three weeks, the acnes started to vanish although those showed some black spots in my face. That my bad experience with adolescence

The italic and underline words are errors in Ignorance of Rules Restriction. we swimming in the beach until maghrib should we were swimming in the beach until maghrib, We all very happy should be We were all very happy, I were thirteen should be I were thirteen and That my bad experience with adolescence should be That was my bad experience with adolescence. From this answer, student do not understand to put the verb of be in the sentence of recount text.

\section{Incomplete Application of Rules}

In the first meeting, student had been made simple past tense.there was "Si Pitung and Si Komar are brave man". The sentence was wrong. It should be Si Pitung and Si Komar were brave man. in the second meeting, student made recount text. There were example student worksheet that have error in Incomplete Application of Rules.

$\underline{\text { Student } 1}$

Last Holiday, me and my family went to the Pelabuhan Ratu Beach. We stay in a small house during 2 days. There are a lot of boat and a lot of fisherman that catch a fish.

First, we enjoyed the beautiful view. And then we sleeps because we are tired. After we sleep, we swimming in the beach until maghrib. Next, we took a shower and prayed maghrib together. Then, we had a dinner and watched TV together. Finally, everybody feel asleep there

We woke up in the morning and after we take a pray subuh together we had a breakfast. In the afternoon we went home. We all very happy

\section{$\underline{\text { Student } 2}$}

I had my adolescence when I were thirteen. It start with acne that showed up on my face. It is very annoying. It lowered my self-esteem and $\underline{I}$ $\underline{a m}$ embarrassed to come out of my house and play with friends. Fortunately, my Mum gave me a good medicine. In three weeks, the acnes started to vanish although those showed some black spots in my face. That my bad experience with adolescence

The italic and underline words are errors in Incomplete application of rules. There are a lot of should be There were, we are tired should be we 
were tired, I were thirteen should be I was thirteen, $\underline{\text { It } i s}$ very annoying should be $\underline{I t}$ was very annoying, and $\underline{I \text { am }}$ embarrassed should be $\underline{I \text { was }}$ embarrassed. From this answer, student failed to apply a complete structure in simple past tense, the error categories as omission of be.

\section{False Concept Hypothesis}

In the first meeting, student had been made simple past tense.there was "i have two brother and one sister". The sentence was wrong. It should be "i have two brothers and one sister". in the second meeting, student made recount text. There were example student worksheet that have error in False Concept Hypothesis :

\section{$\underline{\text { Student } 1}$}

Last Holiday, me and my family went to the Pelabuhan Ratu Beach. We stay in a small house during 2 days. There were a lot of boat and a lot of fisherman that catch many fish.

First, we enjoyed the beautiful view. And then we sleeps because we are tired. After we sleep, we swimming in the beach until maghrib. Next, we took a shower and prayed maghrib together. Then, we had a dinner and watched TV together. Finally, everybody feel asleep there

We woke up in the morning and after we take a pray subuh together we had a breakfast. In the afternoon we went home. We all very happy

\section{$\underline{\text { Student } 2}$}

I had my adolescence when I were thirteen. It start with acne that showed up on my face. It is very annoying. It lowered my self-esteem and I am embarrassed to come out of my house and play with friends. Fortunately, my mum gave me a good medicine. In three weeks, the acnes started to vanish although those showed some black spots in my face. That my bad experience with adolescence

The italic and underline words are errors in false concept hypothesis. many fish should be many fishes. From this answer, student did not understand with singular and plural from sentence.

Precentage of students' error on simple past tense :

a. Overgeneralization : $\frac{4}{25} \times 100 \%=$ $16 \%$

b. Ignorance of Rules Restriction : $\frac{4}{25} \times 100 \%=16 \%$

c. Incomplete Application of Rules : $\frac{2}{25} \times 100 \%=8 \%$

d. False Concept Hypothesis : $\frac{1}{25} \times 100 \%=4 \%$

Students who can make the correct simple past tense sentence : 15

$$
\frac{15}{25} \times 100 \%=60 \%
$$

Precentage of students' error on simple past tense :

a. Overgeneralization : $\frac{25}{82} \times 100 \%=30,1 \%$

b. Ignorance of Rules Restriction : $\frac{22}{82} \times 100 \%=26,8 \%$

c. Incomplete Application of Rules : $\frac{21}{82} \times 100 \%=25,6 \%$

d. False Concept Hypothesis $\frac{14}{82} \times 100 \%=17,1 \%$

Students who can make the correct recount text using simple past tense : 2

$$
\frac{2}{25} \times 100 \%=8 \%
$$




\section{DISCUSSION}

In this section, the writer discussed the result of document review in order to answer the research problem listed in the first chapter. The research problemsare:

1. What kind of error do students make in simple past tense in teaching writing Recount Text At Eight Grade In SMP AlBaisuny?

The following kind of error do students make in simple past tense in writing recount text based on the document review result of the writer:

The error in simple past tense sentence:

a. Overgeneralization : $\frac{4}{25} \times 100 \%=$ $16 \%$

b. Ignorance of Rules Restriction : $\frac{4}{25} \times 100 \%=16 \%$

c. Incomplete Application of Rules : $\frac{2}{25} \times 100 \%=8 \%$

d. False Concept Hypothesis : $\frac{1}{25} \times 100 \%=4 \%$

The students' error in recount writing focused in simple past tense :

a. Overgeneralization : $\frac{25}{82} \times 100 \%=30,1 \%$ This error happened because teacher did not teach clearly simple past tense to the teacher.

b. Ignorance of Rules Restriction : $\frac{22}{82} \times 100 \%=26,8 \%$

This error happened because teacher did not apply auxiliry of simple past tense well, so the student have error in it.

c. Incomplete Application of Rules : $\frac{21}{82} \times 100 \%=25,6 \%$
Student failed to apply a complete structure in simple past tense, the error categories as omission of be.

d. False Concept Hypothesis

$$
\frac{14}{82} \times 100 \%=17,1 \%
$$

Student did not understand with singular and plural from sentence. Teacher did not explain about it when teaching learning process

According to the students worksheet, in document review, the researcher concluded that the kind of error do students make in simple past tense in writing recount text at eight greade in SMP A-Baisuny were almost balance each other. Most of the eight grade students of SMP AlBaisuny can not understand well about simple past tense especially use of it on recount text.

\section{CONCLUSIONAND SUGGESTION}

Written test performed twice, the first test and second test. Through a written test at the time of the first test the result showed that student do not understand how to make a recount text in simple past tense, because the student has not given explanation clearly matter of recount text using simple past tense. Only 15 of $25(60 \%)$ students who can make the correct sentence. While in test data collection ans students were given an explanation matter of recount text using simple past tense. in the result of this test, 2 of 25 (8\%) students who can make recount text using simple past tense. Therefore, there has been decreased $52 \%$ understanding of the recount text using simple past tense. It means that student still difficult to make recount text altough they know to make simple past tense sentence. It cause of the teacher did not give more exercise to the student. So, the student be obvious to appy simple past tense into recount text. 
Errors are often made by students included in this type of generalization errors and ignorance of rules restriction. To minimize the occurance of these errors, students are given simple recount text, then students are asked to make a recount text using simple past tense. So that, it is clear that teaching simple past tense and writing recount will grow learners 'interest of the success in learning writing process.

Based on conclusions above, it can be said that teaching simple past tense to increase students' writing ability of recount text was good enough, in order that the researcher suggest, follow:

It is better if the teacher teach simple past tense of recount text writing in teaching writing, As errors inevitable, a teacher of English should lead his/her students to find out and overcome the errors they made, If the errors indicated the students' misunderstanding of certain rules, it would be better to review the trouble in a small class of remidial teaching.

\section{REFERENCES}

Harmer. 2001. The Practice of English Language Teaching. Longman

Widhiyanti, T. 2008. KTSP (Kurikulum Tingkat Satuan Pendidikan). Indonesia

Uchiyama, Kent. 2006. English Verb Tenses : An Informal Reference for ESL students, the good folk who teach them, and the idly curious.London: Cambridge University Press

Evi.H. 2008. A Correlation Between Students' Mastery of Past Tense and Their Achievement in Writing Recount. Unpublished S1 Skripsi. Universitas Semarang

Trudy Wallace, Winifred E. Stariba, \& Herberts J. Walberg. 2001. Teaching Speaking, Listening and Writing, London: International Bureau of Education

Arifian Rosyadi, 2001. Learning Material Junior High School. Yogyakarta: PT.Gramedia

Palmer F.R. 1998. Grammar and Meaning. England: Houghton Mifflin

Freud Robert. 2001. The English Verb Tense System. New York : Cambridge niversity Press

Halliday, \& Hasan. R. 1989. Aspects od Language in a Socialsemiotic Perspective. New York: Oxford University Press

Low Francis. 2011. English Text and Images. Text and Non Text, 8(9): 19-25

Arikunto, Suharsini. 2006. ProsedurPenelitian. Jakarta: PT Asdi Maha Satya.

Sugiono. 2009. Metode penelitian kualitatif,kuantitatif dan $R \& D$. Bandung : Alfabeta 